\title{
Argyrophilic nucleolar organizer regions as a promising biomarker for the detection of brain hypoxia levels caused by different doses of carbon monoxide poisoning
}

\author{
Kerim Yesildag1, Kamil Kokulu², Huseyin Mutlu², Recep Eroz ${ }^{3}$, Ekrem Taha-Sert² and Ayhan Saritas ${ }^{2 *}$ \\ ${ }^{1}$ Department of Chest Diseases, Konya Numune Hospital, Konya; ${ }^{2}$ Department of Emergency Medicine, Faculty of Medicine, Aksaray University, \\ Aksaray; ${ }^{3}$ Department of Medical Genetics, Faculty of Medicine, Aksaray University, Aksaray. Turkey
}

\begin{abstract}
Objectives: The purpose of the study is to investigate whether there is any relationship between mean argyrophilic nucleolar organizing regions (AgNOR) number and total AgNOR area/total nuclear area (TAA/TNA) ratio and the levels of brain hypoxia after exposure to different acute doses of carbon monoxide (CO) gas. Methods: Each experimental group was exposed to $\mathrm{CO}$ gas (concentrations of 1,000, 3,000 and 5,000 ppm). Then, the rats were anesthetized, and blood samples were taken from the right jugular vein for carboxyhemoglobin levels detection. The rats were sacrificed on seventh day. AgNOR staining was applied to brain tissues. TAA/TNA and mean AgNOR number were detected for each nucleus. Results: Significant differences were detected among all groups for TAA/TNA ratio, mean AgNOR number and carboxyhemoglobin level. According to a double comparison of groups, the differences between control and 1,000 ppm, control and 3,000 ppm, control and 5,000 ppm, and between 1,000 and 5,000 ppm were significant for TAA/TNA ratio. When mean AgNOR number was considered, significant differences were detected between control and 1,000 ppm, control and 3,000 ppm, control and 5,000 ppm, and between 1,000 and 3,000 ppm. Conclusion: AgNOR proteins may be used for early detection of the duration, intensity, and damage of brain injury caused by $\mathrm{CO}$ poisoning. Thus, effective treatment strategies can be developed for the prevention of hypoxic conditions.
\end{abstract}

KEY WORDS: Argyrophilic nucleolar organizer regions. Brain. CO poisoning. Nucleolar organizer regions. rDNA.

\section{Regiones organizadoras nucleolares argirófilas como un biomarcador esperanzador para la detección de niveles de hipoxia cerebral causados por diferentes dosis de intoxicación de monóxido de carbono}

\section{Resumen}

Objetivos: El objetivo del estudio es investigar si existe alguna relación entre el número medio de regiones organizadoras nucleolares argirófilas (AgNOR) y la proporción de área total de AgNOR/área nuclear total (TAA/TNA) y los niveles de hipoxia cerebral en la exposición a diferentes dosis agudas de gas monóxido de carbono (CO). Métodos: Cada grupo experimental fue expuesto a gas CO (concentraciones de 1,000, 3,000 y 5,000 ppm). Luego las ratas fueron anestesiadas, se tomaron muestras de sangre de la vena yugular derecha para la detección de los niveles de carboxihemoglobina. Las ratas se sacrificaron el séptimo día. Se aplicó tinción con AgNOR en los tejidos cerebrales. Se detectaron el TAA/TNA y el número medio de AgNOR para cada núcleo. Resultados: Se detectaron diferencias significativas entre todos los grupos para la relación TAAITNA, el número medio de AgNOR y el nivel de carboxihemoglobina. Según la doble comparación de grupos, las 
diferencias entre control y 1,000 ppm, control y 3,000 ppm, control y 5,000 ppm y 1,000 y 5,000 ppm fueron significativas para la relación TAA/TNA. Cuando se consideró el número de AgNOR medio, se detectaron diferencias significativas entre control y 1,000ppm, control y 3,000ppm, control y 5,000 ppm y 1,000 y 3,000 ppm. Conclusión: Las proteínas AgNOR pueden usarse para la detección temprana de la duración, intensidad y daño de la lesión cerebral causada por la intoxicación por CO. Por lo tanto, se pueden desarrollar estrategias de tratamiento efectivas para la prevención de condiciones hipóxicas.

PALABRAS CLAVE: Regiones organizadoras nucleolares argirofilicas. Cerebro. Intoxicación por CO. Regiones organizadoras nucleolares. ADNr.

\section{Introduction}

Carbon monoxide $(\mathrm{CO})$ gas is non-irritating, tasteless, odorless, colorless, and is formed as a result of incomplete combustion of carbon-containing substances. $\mathrm{CO}$ gas sources include fires, wildfires, faulty gas boilers, motor vehicle exhaust fumes, etc. There are 20,000-50,000 cases of CO-exposure poisoning in the US every year. CO poisoning is known as the cause of many fatal poisonings in some countries'.

$\mathrm{CO}$ gas rapidly diffuses through alveolar capillary membranes, binds to oxygen and leads to the formation of carboxyhemoglobin ( $\mathrm{COHb})$. $\mathrm{CO}$ affinity for $\mathrm{Hb}$ is approximately 200-250 times higher than that of oxygen. CO poisoning causes hypoxia in the body, and the brain is one of the organs that is most sensitive to hypoxia. Hippocampal atrophy and changes in subcortical structures and globus pallidus have been observed $^{1,2}$.

Nucleolar organizer regions (NORs) are genetic loci on chromosomes. These regions are produced from proteins and ribosomal DNA (rDNA), with some corresponding to argyrophilic features. NORs are DNA loops, repeated in series with intergenic spacers and transcribed into ribosomal RNA (rRNA), which is part of mature ribosomes in nucleoli, and finally becomes part of mature ribosomes in the cytoplasm. NORs are functional subunits of the nucleolus ${ }^{3}$.

To the best of our knowledge, there are no studies on the relationship between $\mathrm{CO}$ poisoning and argyrophilic nucleolar organizer region-associated proteins (AgNORs) in brain tissues. AgNORs reveal the metabolic activity, proliferation and self-renewal potential of cells damaged in ischemic events. Therefore, our objective was to evaluate the potential effects of $\mathrm{CO}$ poisoning on brain tissue NOR protein synthesis and to investigate whether there is any relationship not only between the amount of AgNOR protein and $\mathrm{COHb}$ levels, but also between the degree of hypoxia and both AgNOR amounts (mean AgNOR number and total AgNOR area/ total nuclear area ratio [TAA/TNA]) in current study.

\section{Materials and methods}

\section{Experimental procedures}

The present study was approved in accordance with internationally accepted principles for the care and use of laboratory animals by the local ethics committee for animal experiments. We used brain tissues of the rats that were employed in a previous study ${ }^{2}$. Twenty adult male albino Wistar rats (between 150 and $180 \mathrm{~g}$ of weight) selected from the same breed were included in the study.

Four groups were formed, each one containing five rats as follows:

- Group A: control group (consisting of rats exposed to room air).

- Group B: formed by rats exposed to $\mathrm{CO}$ at low concentration (mixture of room air and 1,000 ppm of $\mathrm{CO}$ ).

- Group C: formed by rats exposed to CO at medium concentration (mixture of room air and 3,000 ppm of CO).

- Group D: composed of rats exposed to CO at high concentration (mixture of room air and $5,000 \mathrm{ppm}$ of $\mathrm{CO}$ ).

Three steel tubes (Habas, Industrial and Medical Gases Production Industries Inc., Kocaeli, Turkey) containing $10 \mathrm{~L}$ of $\mathrm{CO}$ gas and different air mixture concentrations $(1,000,3,000$ and $5,000 \mathrm{ppm})$ were used. All rats were exposed to $\mathrm{CO}$ gas in a closed plastic chamber (size: $20 \times 40 \times 60 \mathrm{~cm}^{3}$ ). There were two $2-\mathrm{cm}$ diameter openings (outlet and inlet) on the plastic chamber opposite sides.

Groups B, C and D were exposed to CO gas at three densities (1,000 ppm, 3,000 ppm and 5,000 ppm) with a flow rate of $4 \mathrm{~L} /$ minute for 30 minutes in the plastic chamber. After seven days of exposure, the rats were anesthetized with $50 \mathrm{mg} / \mathrm{kg}$ of ketamine hydrochloride by intraperitoneal route (Ketalar, Parke-Davis, Eczacibasi, Istanbul-Turkey) and $3 \mathrm{mg} / \mathrm{kg}$ of xylazine hydrochloride by intraperitoneal route (Rompun, Bayer 
$A G$, Leverkusen-Germany). Blood samples for the detection of $\mathrm{COHb}$ level were obtained from the right jugular vein by catheterization on each group. After the blood sample was taken, the catheter was removed.

Under anesthesia, the rats were placed in the supine position, the chest wall was shaved and disinfected using a $10 \%$ povidone iodine solution for the surgical procedure. Thoracotomy was performed through a midline incision. Fixation by perfusion was obtained with a $10 \%$ formaldehyde solution (administered by intracardiac route). Brain tissues were then excised and placed in a $10 \%$ formaldehyde solution for fixation. After that, tissues were embedded in paraffin blocks after the usual tissue processing protocols.

\section{AgNOR proteins detection}

$4 \mu \mathrm{m}$-thick sections of brain tissue were obtained, deparaffinized in xylene solution and rehydrated in graded alcohol solutions. The slides were then airdried at room temperature for 15 minutes and subsequently fixed in absolute methanol for 5 minutes. AgNOR staining was applied interchangeably using a modified form of the Benn and Perle ${ }^{4}$ and Lindner ${ }^{5}$ protocols. The slides were evaluated using a light microscope (Olympus CHK 2, Olympus, Japan), and brain tissues were photographed with a digital camera (Axio Cam ICc5, ZEISS, Germany). The captured images were transferred to a digital image processing program (ImageJ 1.53f, National Institutes of Health, Bethesda, Maryland, USA). AgNOR area and nuclear area measurements were updated using the "freehand selection" tool. Fifty nuclei were evaluated per rat and the TAA/TNA ratio and mean AgNOR number were detected for each brain cell nucleus.

\section{Laboratory analysis}

$\mathrm{COHb}$ levels were measured with blood gas analysis. The relationship between $\mathrm{COHb}$ levels and brain tissues was evaluated. Blood gas analysis was carried out using the ABL 800 device (Radiometer, Carlsbad, California, USA).

\section{Statistical analysis}

The Statistical Package for Social Sciences (SPSS), version 22 , was used for statistical analysis. When the study results were evaluated, in addition to descriptive statistics (number, mean, standard deviation, median and range), Kruskall-Wallis test was used for the comparison of all groups, whereas Mann-Whitney's U-test was resorted to for pairwise comparison of groups. In addition, a polynomial regression test was performed. A $p$-value $<0.05$ was accepted as statistically significant.

\section{Results}

Mean AgNOR number and TAA/TNA ratio of each subgroup as well as AgNOR number and TAA/TNA ratio averages are shown in table 1 . When all groups were considered, statistically significant differences were detected between all groups both for TAA/TNA ratio ( $\left.\chi^{2}: 14.417 ; p=0.002\right)$ and mean AgNOR number $\left(\chi^{2}: 14.339 ; p=0.002\right.$ ), respectively (Table 1 and Fig. 1). To understand these differences caused by the groups, a binary comparison was performed between them. According to group-wise double comparison for the TAA/TNA ratio, the differences between control and 1,000 ppm ( $Z$ : $-2.611 ; p=0.009)$, control and $3,000 \mathrm{ppm}(\mathrm{Z}:-2.611 ; \mathrm{p}=0.009)$, control and 5,000 ppm (Z: $-2.611 ; p=0.009)$ and between 1,000 and $5,000 \mathrm{ppm}(Z:-2.611 ; p=0.009)$ were statistically significant. Conversely, the differences between 1,000 and 3,000 ppm ( $Z:-1.149 ; p=0.251)$ and between 3,000 and 5,000 ppm $(Z:-1.149 ; p=0.251)$ were not significant for the TAA/TNA ratio (Table 2).

When mean AgNOR number was taken into account, statistically significant differences were detected between control and 1,000 ppm ( $Z:-2.611 ; p=0.009)$, control and $3,000 \mathrm{ppm}(\mathrm{Z}:-2.611 ; p=0.009)$, control and $5,000$ ppm ( $Z:-2.611 ; p=0.009)$ and between 1,000 and 3,000 ppm ( $Z:-2.514 ; p=0.012)$. Conversely, the differences between 1,000 and 5,000 ppm ( $Z$ : -0.419 ; $p=0.675)$ and between 3,000 and $5,000 \mathrm{ppm}$ (Z: $-1.776 ; p=0.076)$ were not significant for mean AgNOR number (Table 2). In addition, statistically significant differences were detected between all groups for COHb ( $\left.\chi^{2}: 16.995 ; p=0.001\right)$ (Table 3).

To detect the relationship between $\mathrm{COHb}$ levels and AgNOR amounts, a polynomial regression analysis was carried out, with a statistically significant relationship being detected between $\mathrm{COHb}$ levels and mean AgNOR number in brain cells $(p<0.05)$ (Table 4 , Fig. 1C). In addition, the relationship between brain cells TAA/TNA ratio and $\mathrm{COHb}$ levels was also statistically significant $(p<0.05)$ (Table 4, Fig. 1D). 
Table 1. Argyrophilic nucleolar organizer regions (AgNORs) mean number, total AgNOR area/total nuclear area (TAA/TNA) ratio of each subgroup and their mean AgNOR number and TAA/TNA ratio

\begin{tabular}{|c|c|c|c|c|c|c|}
\hline Groups & $\begin{array}{c}\text { Mean AgNOR } \\
\text { number } \pm S D(n=50)\end{array}$ & $\begin{array}{l}\text { Mean TAA/TNA } \\
\pm S D(n=50)\end{array}$ & $\begin{array}{l}\text { Group AgNOR number } \\
\text { average/median (range) } \\
\qquad(n=250)\end{array}$ & $\begin{array}{l}\text { Group TAATNA average/ } \\
\text { median (range) }(n=250)\end{array}$ & $x^{2}$ & p \\
\hline C1 & $1.56 \pm 0.760$ & $0.066 \pm 0.017$ & \multirow[t]{5}{*}{$1.565 \pm 0.071 / 1.56(0.19)$} & \multirow[t]{5}{*}{$0.063 \pm 0.002 / 0.064(0.006)$} & \multirow{20}{*}{$\begin{array}{l}14.339^{\star} \\
14.417^{\dagger}\end{array}$} & \\
\hline C2 & $1.46 \pm 0.579$ & $0.060 \pm 0.019$ & & & & $\begin{array}{l}0.002^{*} \\
0.002^{\dagger}\end{array}$ \\
\hline C3 & $1.549 \pm 0.541$ & $0.064 \pm 0.015$ & & & & \\
\hline C4 & $1.647 \pm 0.796$ & $0.064 \pm 0.070$ & & & & \\
\hline C5 & $1.608 \pm 0.532$ & $0.063 \pm 0.016$ & & & & \\
\hline A 1,000 ppm 1 & $2.647 \pm 0.700$ & $0.090 \pm 0.028$ & \multirow[t]{5}{*}{$2.675 \pm 0.140 / 2.686(0.39)$} & \multirow[t]{5}{*}{$0.096 \pm 0.007 / 0.097(0.016)$} & & \\
\hline A 1,000 ppm 2 & $2.863 \pm 0.663$ & $0.104 \pm 0.030$ & & & & \\
\hline A 1,000 ppm 3 & $2.706 \pm 0.807$ & $0.097 \pm 0.025$ & & & & \\
\hline A 1,000 ppm 4 & $2,471 \pm 0.731$ & $0.101 \pm 0.025$ & & & & \\
\hline A 1,000 ppm 5 & $2.686 \pm 0.787$ & $0.088 \pm 0.024$ & & & & \\
\hline A 3,000 ppm 1 & $2.420 \pm 0.785$ & $0.095 \pm 0.020$ & \multirow[t]{5}{*}{$2.241 \pm 0.216 / 2.275(0.49)$} & \multirow[t]{5}{*}{$0.107 \pm 0.015 / 0.112(0.034)$} & & \\
\hline A 3,000 ppm 2 & $2.275 \pm 0.723$ & $0.118 \pm 0.057$ & & & & \\
\hline A 3,000 ppm 3 & $2.059 \pm 0.580$ & $0.122 \pm 0.037$ & & & & \\
\hline A 3,000 ppm 4 & $1.98 \pm 0.589$ & $0.096 \pm 0.015$ & & & & \\
\hline A 3,000 ppm 5 & $2,471 \pm 0.674$ & $0.112 \pm 0.101$ & & & & \\
\hline A 5,000 ppm 1 & $2.961 \pm 1.039$ & $0.113 \pm 0.049$ & \multirow[t]{5}{*}{$2.678 \pm 0.445 / 2.706(1.16)$} & \multirow[t]{5}{*}{$0.123 \pm 0.016 / 0.116(0.037$} & & \\
\hline A 5,000 ppm 2 & $2.039 \pm 0.871$ & $0.105 \pm 0.032$ & & & & \\
\hline A 5,000 ppm 3 & $3.196 \pm 1.200$ & $0.142 \pm 0.057$ & & & & \\
\hline A 5,000 ppm 4 & $2.706 \pm 1.064$ & $0.138 \pm 0.050$ & & & & \\
\hline A 5,000 ppm 5 & $2.490 \pm 1.027$ & $0.116 \pm 0.034$ & & & & \\
\hline
\end{tabular}

Table 2. Results of the groups double comparison for total AgNOR area/total nuclear area ratio (TAA/TNA) and argyrophilic nucleolar organizer regions (AgNORs) mean number

\begin{tabular}{|c|c|c|c|c|c|c|c|c|c|}
\hline & \multirow[t]{2}{*}{ Groups } & \multicolumn{2}{|c|}{ C } & \multicolumn{2}{|c|}{1,000 ppm } & \multicolumn{2}{|c|}{ 3,000 ppm } & \multicolumn{2}{|c|}{5,000 ppm } \\
\hline & & $\mathbf{z}$ & p & $\mathbf{z}$ & p & $\mathbf{z}$ & $p$ & $\mathbf{Z}$ & p \\
\hline \multirow[t]{4}{*}{ TAA/TNA } & C & - & - & -2.611 & 0.009 & -2.611 & 0.009 & -2.611 & 0.009 \\
\hline & $1,000 \mathrm{ppm}$ & -2.611 & 0.009 & - & - & -1.149 & 0.251 & -2.611 & 0.009 \\
\hline & $3,000 \mathrm{ppm}$ & -2.611 & 0.009 & -1.149 & 0.251 & - & - & -1.149 & 0.251 \\
\hline & $5,000 \mathrm{ppm}$ & -2.611 & 0.009 & -2.611 & 0.009 & -1.149 & 0.251 & - & - \\
\hline \multirow[t]{4}{*}{ Mean AgNOR number } & C & - & - & -2.611 & 0.009 & -2.611 & 0.009 & -2.611 & 0.009 \\
\hline & $1,000 \mathrm{ppm}$ & -2.611 & 0.009 & - & - & -2.514 & 0.012 & -0.419 & 0.675 \\
\hline & $3,000 \mathrm{ppm}$ & -2.611 & 0.009 & -2.514 & 0.012 & - & - & -1.776 & 0.076 \\
\hline & 5,000 ppm & -2.611 & 0.009 & -0.419 & 0.675 & -1.776 & 0.076 & - & - \\
\hline
\end{tabular}



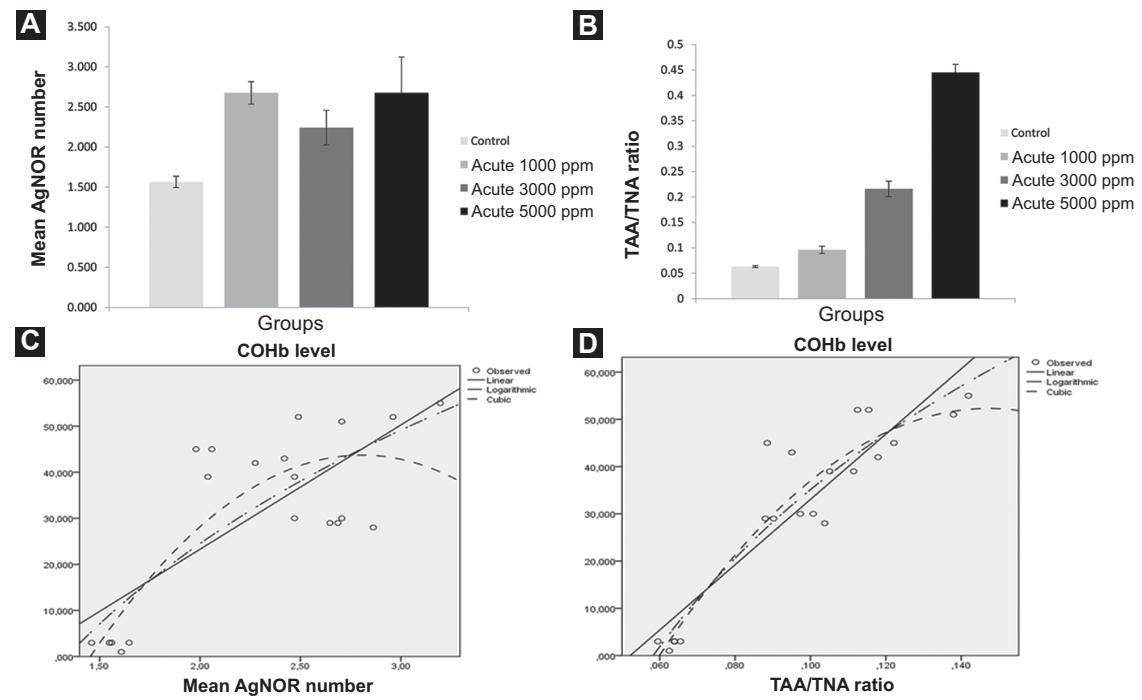

Figure 1. Comparison of argyrophilic nucleolar organizing regions (AgNOR) mean number (A) and total AgNOR area/total nuclear area (TAA/ TNA) ratio (B) of the groups. Relationship between brain cells' mean AgNOR number and carboxyhemoglobin (COHb) levels (C) and between brain cells' mean TAA/TNA ratio and $\mathrm{COHb}$ levels (D).

\section{Experimental demonstration of carbon monoxide toxicity in vivo}

Brain hypoxia caused by carbon monoxide poisoning induces cell damage and a response is produced in the nucleus. rDNA genes are replicated from the nucleus, rRNAs are transcribed from rDNA, and NORs are translated from rRNA. NOR stained with silver in brain cells exposed different $\mathrm{CO}$ levels (control and $1,000,3,000$ and 5,000 ppm for brain cells) (Fig. 2).

\section{Discussion}

The appearance of inflammation, oxidative stress, oxygen radicals and apoptosis is comparable to a reperfusion injury and constitutes a mechanism of significant harm. Neurologic lesions will occur in the long term (concentration deficit, dementia, ataxias or abnormal behavior, etc.). Changes can be observed in the globus pallidus and subcortical structures. The severity of initial poisoning cannot be correlated with the development of long-term neuronal damage'.

Oxygen concentrations can be reduced by different internal and external agents such as $\mathrm{CO}$ poisoning. This situation causes hypoxia and acidosis of different cells such as those of the heart, lung, muscle, brain, etc. In this condition, structural and functional damage of different tissues and cells can occur depending on the duration, time and degree of hypoxia. Therefore, early detection of the duration, time and degree of hypoxia is of great importance not only for reducing hypoxia-induced damage, but also for the development of an efficacious treatment strategy.

Measurements of AgNOR protein amounts (especially the TAA/TNA ratio) by means of software provide more reliable results about the changes of these proteins. The AgNOR staining technique is an efficacious, reliable, inexpensive and sensitive method for evaluating ischemic brain damage. In addition, AgNORs are a good indicator for the detection of proliferation, metabolic activity, ribosomal subunits formation, protein synthesis capacity of cells, and self-renewal potential of cells damaged by ischemic events. For this reason, various studies have been carried out on different cells such as human hair root cells $s^{6}$, buccal epithelial cells in infants with Down syndrome $^{7}$ and healthy subjects ${ }^{8}$, benign and malignant thyroid cells ${ }^{9-12}$, different types of cancer cells $s^{13-15}$ and hypoxia caused by $\mathrm{CO}$ poisoning on different cells $\mathbf{s}^{2,3,16-18}$. According to our results, in the first study in the literature on brain exposure to $\mathrm{CO}$ poisoning, statistically significant differences were detected between all groups both for TAA/TNA ratio and mean AgNOR number. According to the double comparison of groups, the differences between control and $1,000 \mathrm{ppm}$, control and 3,000 ppm, control and $5,000 \mathrm{ppm}$ and between 1,000 and 5,000 ppm were statistically significant for the TAA/TNA ratio. In addition, statistically significant differences were detected between control and 1,000 ppm, control and 
Table 3. Comparison of carboxyhemoglobin $(\mathrm{COHb})$ levels in all groups

\begin{tabular}{|c|c|c|c|c|}
\hline Groups & Mean $\mathrm{COHb}(n=50)$ & Group COHb average/median (range) $(n=250)$ & $x^{2}$ & p \\
\hline $\mathrm{C} 1$ & 3 & \multirow[t]{5}{*}{$2.6 \pm 0.894 / 3(2)$} & \multirow[t]{20}{*}{16.995} & \multirow[t]{20}{*}{0.001} \\
\hline C2 & 3 & & & \\
\hline C3 & 3 & & & \\
\hline C4 & 3 & & & \\
\hline C5 & 1 & & & \\
\hline A 1,000 ppm 1 & 29 & \multirow[t]{5}{*}{$29.2 \pm 0.837 / 29(2)$} & & \\
\hline A 1,000 ppm 2 & 28 & & & \\
\hline A 1,000 ppm 3 & 30 & & & \\
\hline A 1,000 ppm 4 & 30 & & & \\
\hline A 1,000 ppm 5 & 29 & & & \\
\hline A 3,000 ppm 1 & 43 & \multirow[t]{5}{*}{$42.8 \pm 2.490 / 43(6)$} & & \\
\hline A 3,000 ppm 2 & 42 & & & \\
\hline A 3,000 ppm 3 & 45 & & & \\
\hline A 3,000 ppm 4 & 45 & & & \\
\hline A 3,000 ppm 5 & 39 & & & \\
\hline A 5,000 ppm 1 & 52 & \multirow[t]{5}{*}{$49.8 \pm 6.221 / 52(16)$} & & \\
\hline A 5,000 ppm 2 & 39 & & & \\
\hline A 5,000 ppm 3 & 55 & & & \\
\hline A 5,000 ppm 4 & 51 & & & \\
\hline A 5,000 ppm 5 & 52 & & & \\
\hline
\end{tabular}

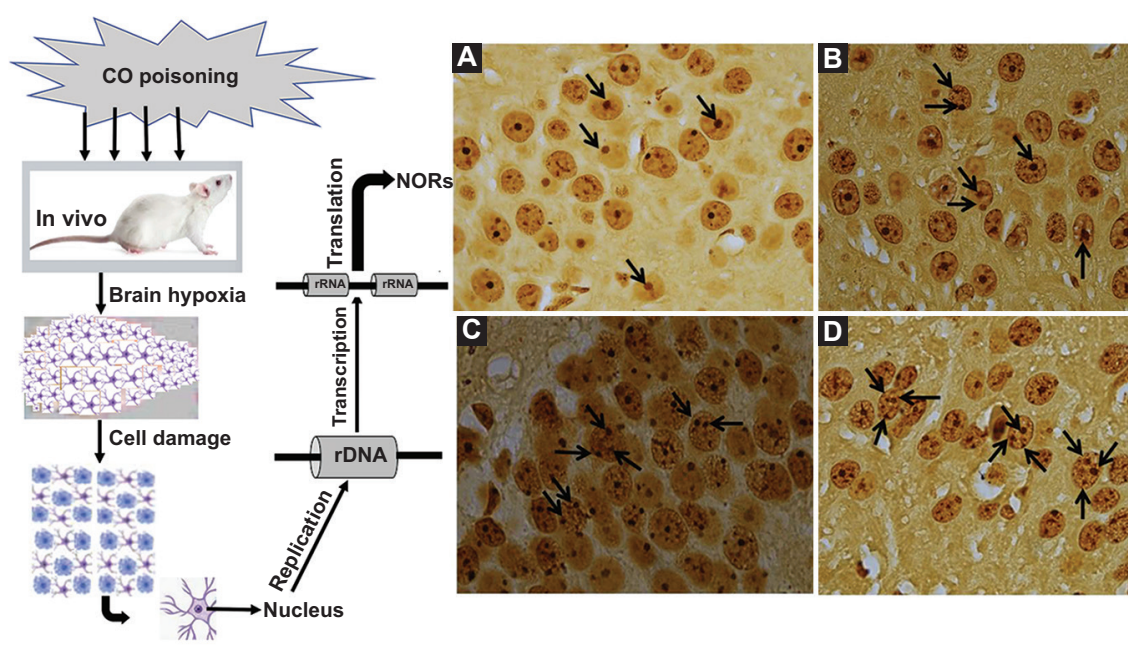

Figure 2. Carbon monoxide (CO) poisoning experimental demonstration in vivo. Brain hypoxia induced by carbon monoxide poisoning causes cell damage and a response is produced in the nucleus. Ribosomal DNA ( $r D N A)$ genes are replicated from the nucleus, ribosomal RNAs ( $r R N A s)$ are transcribed from rDNA, and nucleolar organizer regions (NOR) are translated from rRNA. NORs stained with silver in brain cells exposed to different levels of CO. A: control; B: 1,000 ppm; C: 3,000 ppm; D: 5,000 ppm for brain cells (X100 magnification). 
Table 4. Model summary and parameter estimates for carboxyhemoglobin ( $\mathrm{COHb}$ ) levels and argyrophilic nucleolar organizing regions (AgNOR) mean numbers and total AgNOR area/total nuclear area ratio (TAA/TNA)

\begin{tabular}{|c|c|c|c|c|c|c|c|c|c|c|}
\hline \multirow[t]{2}{*}{ Variable } & \multirow[t]{2}{*}{ Equation } & \multicolumn{5}{|c|}{ Model summary } & \multicolumn{4}{|c|}{ Parameter estimates } \\
\hline & & $\mathbf{R}^{2}$ & $\mathbf{F}$ & df1 & df2 & sig & Constant & b1 & b2 & b3 \\
\hline \multirow[t]{3}{*}{ M-AgNOR-N and $\mathrm{COHb}$} & Linear & 0.567 & 23.544 & 1 & 18 & 0.000 & -30.679 & 26.982 & & \\
\hline & $\log$ & 0.615 & 28,803 & 1 & 18 & 0.000 & -17.556 & 60.703 & & \\
\hline & Cubic & 0.665 & 16.843 & 2 & 17 & 0.000 & -144.662 & 134.271 & -23.926 & 0.000 \\
\hline \multirow[t]{3}{*}{ TAA/TNA and $\mathrm{COHb}$} & Linear & 0.831 & 88.719 & 1 & 18 & 0.000 & -36.059 & 691.112 & & \\
\hline & Logarithmic & 0.874 & 124.603 & 1 & 18 & 0.000 & 184.976 & 65.081 & & \\
\hline & Cubic & 0.885 & 65.595 & 2 & 17 & 0.000 & -96.421 & 2019.695 & -6856.583 & 0.000 \\
\hline
\end{tabular}

M-AgNOR-N: mean AgNOR number.

3,000 ppm, control and 5,000 ppm and between 1,000 and 3,000 ppm for mean AgNOR number.

Previously, we reported that the level of AgNOR proteins increased depending on the duration and levels of $\mathrm{CO}$ exposure in the lung ${ }^{2}$, myocytes ${ }^{3,16}$ and muscle cells ${ }^{17,18}$. In the present study, the levels of AgNOR proteins also did significantly increase depending on the levels of $\mathrm{CO}$ exposure in brain cells. In addition, the relationships between $\mathrm{COHb}$ levels and AgNOR amounts (mean AgNOR numbers and TAA/TNA ratio) were statistically significant.

All living organisms must protect themselves from external and internal dangerous agents such as $\mathrm{CO}$ poisoning. Can AgNOR proteins be synthesized against $\mathrm{CO}$ poisoning for protective purposes or trigger the synthesis of other proteins that have a protective effect on the regulation of signal and gene transduction pathways in CO-poisoning conditions? Can these proteins be used as therapeutic agents to prevent the dangerous effects of $\mathrm{CO}$ poisoning? Hypoxia and asphyxia are a major health problem faced by humanity and can cause serious damages to the organism's life. Therefore, can the administration of these proteins to individuals at risk of hypoxic and asphyxiating birth, such as oral B12 and folate, reduce the sequelae? Can deficiencies of some organs during embryonic morphogenesis be reduced using those proteins? Further studies including large series are needed for this issue to be more clearly understood.

In conclusion, AgNORs provide information on the metabolic activity, proliferation and self-renewal potential of cells damaged by ischemic events. Furthermore, AgNOR proteins can be used for early detection of the duration, intensity and damage of $\mathrm{CO}$ poisoning in brain cells. Therefore, effective treatment strategies can be developed for the prevention of hypoxic conditions.

\section{Funding}

This research has not received any specific grants from agencies of the commercial, public or non-profit sectors.

\section{Conflict of interests}

The authors declare that they have no conflicts of interest.

\section{Ethical disclosures}

Protection of human and animal subjects. The authors declare that the procedures that were followed adhered to the ethical standards of the responsible committee for experimentation on human beings and were in agreement with the World Medical Association and the Declaration of Helsinki.

Confidentiality of data. The authors declare that no patient data appear in this article.

Right to privacy and informed consent. The authors declare that no patient data appear in this article.

\section{References}

1. Eichhorn L, Thudium M, Jüttner B. The diagnosis and treatment of carbon monoxide poisoning. Dtsch Arztebl Int. 2018;115:863-70.

2. Colakoglu S, Saritas A, Eroz R, Oktay M, Yaykasli KO, Akoz A, et al. Is one-time carbon monoxide intoxication harmless? Evaluation by argyrophilic nucleolar-organizing regions staining method. Hum Exp Toxicol. 2015;34(1):24-31.

3. Saritas A, Gunes H, Colakoglu S, Eroz R, Akoz A, Oktay M, et al. Are there any effects of chronic carbon monoxide exposure on argyrophilic nucleolar-organizing region-associated protein synthesis in rat myocardium? Hum Exp Toxicol 2016;35(9):921-8. 
4. Benn PA, Perle M. Técnicas de tinción y bandas de cromosomas In: Rooney DE, Czepulkowski BH, publishers. Citogenética humana, Análisis constitucional, enfoque práctico, Vol. 1. Oxford: Oxford University Press; 1986. pp. 91-118.

5. Lindner LE. Improvements in the silver-staining technique for nucleolar organizer regions (AgNOR). J Histochem Cytochem. 1993;41(3):439-45.

6. Eroz R, Yilmaz S, Cucer N. Argyrophilic nucleolar organizing region associated protein synthesis in hair root cells of humans at different developmental stages and sex. Biotech Histochem. 2013;88:267-71.

7. Eroz R, Okur M, Ozkan A, Berik O, Gunes C. Does higher NORs expression affect the developmental stages of Down syndrome infants? Genet Couns. 2012;23(2):249-53.

8. Selvi B, Demirtas H, Eroz R, Imamoglu N. Reduction of the argyrophilic nucleolar organizing region associated protein synthesis with age in buccal epithelial cells of healthy individuals. Aging Clin Exp Res. 2015;27(2):201-8

9. Eroz R, Cucer N, Karaca Z, Unluhizarci K, Ozturk F. The evaluation of argyrophilic nucleolar organizing region proteins in fine-needle aspiration samples of thyroid. Endocr Pathol. 2011;22:74-8.

10. Eroz R, Cucer N, Unluhizarcı K, Ozturk F. Detection and comparison of cut-off values for total AgNOR area/nuclear area and AgNOR number/ nucleus in benign thyroid nodules and normal thyroid tissue. Cell Biol Int. 2013;37(3):257-61.

11. Eroz R, Unluhizarcı K, Cucer N, Ozturk F. Value of argyrophilic nucleolar organizing region protein determinations in nondiagnostic fine needle aspiration samples (due to insufficient cell groups) of thyroid nodules. Anal Quant Cytopathol Histpathol. 2013;35:226-32.
12. Oktay M, Eroz R, Oktay NA, Erdem H, Başar F, Akyol L, et al. Argyrophilic nucleolar organizing region associated protein synthesis for cytologic discrimination of follicular thyroid lesions. Biotech Histochem. 2015;90:179-83

13. Eroz R, Alpay M. Investigation of the effect of capsaicin on AgNOR protein synthesis using staining intensity degree in human colon adenocarcinoma. Edorium J Cell Biol. 2018;4:100007C06RE2018. doi: 10.5348/100007C06RE20180A.

14. Ertekin T, Bozkurt O, Eroz R, Nisari M, Bircan D, Nisari M, et al. May argyrophilic nucleolar organizing region-associated protein synthesis be used for selecting the most reliable dose of drugs such as rhamnetin in cancer treatments? Bratisl Lek Listy. 2016;117(11):653-8.

15. Nisari M, Eroz R. Does capsaicin have therapeutic benefits in human colon adenocarcinoma? Selection of the most reliable dose via AgNOR. Turk J Med Sci. 2020;50(4):1076-81.

16. Kandis H, Afacan MA, Eroz R, Colakoglu S, Bayramoglu A, Oktay M, et al. Can argyrophilic nucleolar organizing region-associated protein amount be used for the detection of cardiac damage? Hum Exp Toxicol. 2015;35:323-31.

17. Eroz R, Saritas A, Colakoglu S, Oktay M, Kandis H. Evaluation of argyrophilic nucleolar organizing region-associated protein synthesis in femoral muscle cells of rats exposed $3000 \mathrm{ppm}$ carbon monoxide gas. Konuralp Med J. 2016;8:9-13.

18. Gunes H, Saritas A, Eroz R, Colakoglu S. Use of argyrophilic nucleolarorganizer region-associated protein synthesis in skeletal muscle cells for prediction of chronic carbon monoxide exposure. Tox Rev. 2020;39(4):349-54. 